Article

\title{
Global Warming Potentials Due to Railway Tunnel Construction and Maintenance
}

\author{
Sakdirat Kaewunruen * (D), Jessada Sresakoolchai ${ }^{D}$ and Shuonan Yu
}

School of Engineering, University of Birmingham, Birmingham B15 2TT, UK; JSS814@student.bham.ac.uk (J.S.); sxy803@alumni.bham.ac.uk (S.Y.)

* Correspondence: s.kaewunruen@bham.ac.uk; Tel.: +44-(0)-121-414-2670

Received: 17 August 2020; Accepted: 15 September 2020; Published: 16 September 2020

Featured Application: The new findings highlight the lifecycle cost and carbon footprint of high-speed railway tunnels, which are usually adopted in real-life practices globally. The in-depth insight incites the systems thinking consideration of rail decarbonisation. The method and field data in the article can be used (not limited to) as an indicative reference for revolutionising design, construction and maintenance to achieve the sustainability of high-speed rail infrastructures.

\begin{abstract}
Global warming is a critical issue nowadays. Although the railway system is considered as green transportation, it cannot be denied that railway tunnels have a significant environmental impact during construction and maintenance. At the same time, asset management of a project becomes more popular in project analysis. Therefore, this study aims to analyse life-cycle cost (LCC) and life-cycle assessment (LCA) for the Xikema No. 1 high-speed railway tunnel in China to consider the environmental impact of rail tunnel construction. The initial capital costs of tunnel and rail construction, operation, and maintenance costs have been separately considered in terms of the life-cycle cost analysis and net present value (NPV) with various discount rates. The LCA analysis has presented the $\mathrm{CO}_{2}$ emissions and energy consumption over the construction and operation processes into consideration. The $\mathrm{CO}_{2}$ emissions and energy consumption caused by material production, maintenance, and material transportation have been accounted for. The results show that the materials used during the construction process contribute to about $97.1 \%$ of $\mathrm{CO}_{2}$ emissions of the life-cycle while $\mathrm{CO}_{2}$ emissions caused by the operation and maintenance process are relatively small compared with the construction process. Moreover, the maintenance process consumes over $55 \%$ of the life-cycle energy. The energy consumption of the tunnel construction process is approximately $44.3 \%$. At the same time, the construction contributes to the main proportion of LCC due to relatively low cost in the operation and maintenance stages.
\end{abstract}

Keywords: railway tunnel; life-cycle costs; $\mathrm{CO}_{2}$ emissions; energy consumption; highspeed rail; sustainable development

\section{Introduction}

The railway system plays an important role nowadays due to the increasing demand for transportation for both people and goods. Railway networks, then, need to be extended to serve this increasing demand. At the same time, a hub of transportation also increases the number of passengers around the hub [1]. In addition, investment in the railway system boosts economic growth and employment [2]. During the design stage, designers need to consider the appropriation of the design by many factors. One of the important factors is the topography where projects are constructed. In some cases, constructing by using tunnels cannot be avoided. However, the construction of tunnels is 
complex, time-consuming, costly, and has a high environmental impact. In terms of the environmental impact, $\mathrm{CO}_{2}$ emission is a crucial issue and prioritised widely nowadays.

The Xikema No. 1 railway tunnel has been selected for this analysis because it is the longest railway tunnel of the Jinghu high-speed railway system with a length of $1318 \mathrm{~km}$ and connects the two main economic zones of China which are Beijing and Shanghai. This high-speed railway is also recognised as the longest line constructed during a single phase. Because safety is a critical issue in the railway system and it mainly depends on the inspection [3], maintenance has to be carefully considered besides the design and construction. In addition, a failure to detect the defective components in the railway system can increase the maintenance cost up to 30-35\% [4]. A comprehensive study of the life cycle of the project is required. Therefore, life-cycle cost (LCC) and life-cycle assessment (LCA) analysis of this tunnel will be presented.

The Xikema No. 1 tunnel is located in the Changqing District of Jinan in the Shandong Province where there are 2 main types of soil, Shandong brown soil and sandy ginger soil. It is $2812 \mathrm{~m}$ long which is the longest tunnel of the Jinghu high-speed railway. The construction process of this railway tunnel took place from January 2008 to February 2010.

The objectives of this study can be divided into two main parts, LCC and LCA analysis. A comprehensive LCC analysis of the Xikema No. 1 railway tunnel will be conducted. All the possible costs throughout the overall design life of the tunnel have been detailed and the final life-cycle costs (i.e., net present value (NPV)) are also estimated. Then, details of the LCA analysis of the Xikema No. 1 railway tunnel will be performed which includes all the possible factors that may cause an environmental impact, from the manufacturing of construction materials to the decommissioning of the railway tunnel. Conclusions are also drawn in terms of both LCC and LCA analysis of this high-speed railway tunnel.

\section{Literature Review}

High-speed rail (HSR) systems have been widely used in China especially in the eastern and southern areas. Due to the special geological conditions and the high standards of HSR systems, tunnels are often necessary for a long, high-speed railway line. The HSR tunnel proves to be quite complicated [5] because of the following reasons:

- The construction of a railway tunnel requires a higher number of construction processes compared to normal railway construction. Before a railway's construction, a tunnel should be excavated and supported gradually. These excavation and support processes are likely to be much more complex and time-consuming than subsequent railway construction.

- Compared to normal railway construction, different machines and equipment are used which may lead to more difficult construction management.

- After construction, the operation of a railway tunnel will influence the tunnel itself in various ways.

- A railway tunnel is often very costly and should be designed for long life. Therefore, a tunnel's maintenance and modifications can also be very costly.

- The operation of a railway tunnel needs more personnel and equipment.

Due to the above issues, a lot of money is required to invest in a railway tunnel. Railway tunnel construction can have a significant impact on the environment. Therefore, costs and the environmental impact of railway tunnels require further study based on the currently available analysis of normal railways.

Various approaches are applied to estimate the costs of a railway tunnel system. Generally, these methods can be classified into two categories. One is to perform case studies on given railway lines using a bottom-up method. The other is to take an average system using a top-down method. Levinson et al. [6] applied the case-study method to evaluate the full costs of a high-speed rail system in California including infrastructure, fleet capital and operating costs, time, and social costs (e.g., noise, pollution, and accidents). Kagiyama [7] carried out a similar case study for the high-speed railway system 
between Osaka and Tokyo using the Japanese Shinkansen technology in California. de Rus Mendoza [8] assessed the costs of the construction and operation of a new high-speed railway system. Generally, the case study approach can be useful for the cost evaluation of high-speed railway systems. However, in this case, it is confined to a single specific project and is not able to provide a very general discussion of the costs.

In contrast, the second approach, the top-down method, establishes a much more general model for the estimation of high-speed railway costs. There are two different methods for this approach. The first is the life-cycle cost (LCC) method. LCC is applied only to individual parts of a whole system and evaluates the overall costs throughout an entire life cycle of a high-speed railway system. LCC analysis is an economic assessment that accounts for all possible significant costs over the design life of a railway tunnel [9]. Andrade [10] developed LCC models for the rail and ballast of a railway system which is used for the initial decision-making process of the project. Zhao et al. [11] have performed a similar analysis to optimise ballast tamping and renewal to reduce the LCC of the ballast. The second is the RAMS (reliability, availability, maintainability, and safety) analysis which is useful from a long-term point of view. This method mainly concentrates on the maintenance management of railway systems and operation and maintenance costs throughout the overall life of the design life [12]. Patra [13] developed a method for effective decision making during the maintenance process of a railway system using both LCC and RAMS analysis.

Based on the above analysis, LCC is a more comprehensive cost evaluation method because it can account for each individual portion of costs throughout the overall life of the design. This comprehensive evaluation can support the optimisation of the long-term costs of a project rather than the short-term consideration of costs. According to Flanagan et al. [14], in LCC analysis all possible costs should be accounted for. These costs can be classified into three main parts which are tangible and intangible costs, capital costs and running costs, and costs of ownership and operations. Kaewunruen et al. [15] analysed LCC of each type of maintenance of tracks at railway bridges. Kaewunruen et al. [16] also analysed LCC of high speed rail and found that every stage of the project was significant in terms of LCC. In most cases, it is impossible to obtain convincing and reliable data for estimating maintenance and operations because future operational details are not easy to predict. The Internet of Things (IoT) can play an important role to improve the overall performance of the railway system [15]. With the lack of data availability, reasonable assumptions must be made about possible operation and maintenance conditions in the future. To ensure the robustness of the LCC analysis, sensitivity analysis or uncertainty analysis is necessary to test the assumptions made in the original LCC analysis. Sensitivity analysis usually changes the input values by a small percentage and checks the effect of this change on the final LCC. In uncertainty analysis, the variability of these pre-determined key factors is evaluated first. A Monte Carlo simulation may be applied to examine the reliability of the assumptions of the initially proposed LCC model [17].

In addition to the LCC analysis of a railway system, the life-cycle assessment (LCA) is also of great importance. LCA is an effective and efficient approach for evaluating the environmental impact of a railway project throughout the overall design life. Although LCA has been widely used in many fields, its application to high-speed railway systems has not been extensively studied especially in relation to railway tunnel analysis. Grossrieder [18] summarised the key factors of high-speed railway systems that have an impact on the surrounding environment in Norway. As stated by Qian and Hamdany [19], in their analysis of LCA, inventory analysis was considered to be the most critical factor because it consumed the most resources. Based on the LCA analysis of a high-speed railways system in China [20], reducing the number of bridges and tunnels in the high-speed railway construction will substantially reduce the environmental effects during its life-cycle. This finding was also demonstrated by Du and Karoumi [21] and Vandanjon et al. [22]. Generally, LCA is only considered for the environmental impact of the railway structure itself. However, construction and operation processes indirectly impact on the overall system. The environmental impact of the material manufacturing process can also be very significant [23]. As found by Gervasio et al. [24], the primary environmental impact 
comes from the manufacturing of construction materials especially steel and concrete productions. Therefore, to reduce the environmental impact of railway construction, the optimisations of material manufacturing, operational, and maintenance processes are often recommended [25]. Digital twins can improve the sustainability in terms of LCA to select the most proper solutions in the railway system components such as railway turnout [26], railway stations [27], or railway bridges [28].

\section{Life-Cycle Costs (LCC)}

The life cycle of a structure is always referred to as its full life span covering its construction, operation, and maintenance stages. The life-cycle costs of a high-speed railway tunnel represent all the economic resources required over the design life of the project. These resources include the initial capital costs needed for the construction of necessary facilities and structures, subsequent operation, and maintenance costs used to improve and maintain the project services throughout the overall design life of the project. Among these costs, capital costs are confined to the initial years of construction while operation and maintenance costs are incurred throughout the overall life of the design. These economic resources are usually quantified and discounted back to the present value. This is referred to as the net present value (NPV). This section will discuss the capital costs and operation and maintenance costs separately. Then, the LCC analysis of the tunnel will be conducted. The construction of the tunnel consists of 6 steps which are excavation, muck disposal, primary support installation, ground control measures, ventilation and air conditioning, and permanent lining installation. Most of steps are considered in the construction stage except ventilation and air conditioning which not included in this study.

The Xikema No.1 Tunnel is about $1 \mathrm{~km}$ northeast of Changqing. The location of the tunnel compared to the line is at KM420 + 395 to KM423 + 207. The length of the tunnel is $2.812 \mathrm{~km}$. The range of the slope is $5.5 \%$ to $15 \%$. The maximum design vertical curve is $30,000 \mathrm{~m}$ while the horizontal curve is $7000 \mathrm{~m}$. The width of the tunnel is $8.2 \mathrm{~m}$.

\subsection{Capital Costs}

The capital costs of a railway tunnel mainly include the material and labour costs required for the project's construction. Unlike the construction of a normal high-speed railway, the construction of a railway tunnel requires the tunnel to be excavated and safely supported before the construction of the railway in the tunnel. Due to complex geological and geotechnical conditions, the majority of the capital costs are the construction of the tunnel itself rather than the subsequent railway construction. For this specific railway tunnel, the capital costs of the tunnel's construction are classified into four main portions based on the construction process of the project. The costs of each portion are primarily the material and labour costs of the construction process.

For a rock tunnel, tunnel construction is gradually excavated and supported by III to V wall rocks. Generally, the excavation of the tunnel comes first and then the tunnel is temporarily supported by supporting structures followed by the assembly of tunnel lining as permanent support for the tunnel. Open cut and shed tunnels are also of great importance for safety within a rock tunnel. They are mainly constructed using concrete and rocks. The tunnel's entrances need to be refined to smoothly connect the tunnel to the outside railway sections. The costs of other ancillary work should also be included such as grouted rubble, concrete, the spoil area, and catenary. The construction of this high-speed railway tunnel took about two years to complete. The capital costs of the construction of the railway tunnel are summarised in Table 1 . The information was obtained from the preliminary construction report [29]. The overall capital costs of this railway tunnel were about 24.25 million USD when the main machine was a tunnel boring machine. For simplicity, the total capital costs per year are reasonably assumed to be the same. 
Table 1. Capital costs.

\begin{tabular}{|c|c|c|c|c|}
\hline \multicolumn{3}{|c|}{ Items } & $\begin{array}{l}\text { Capital Cost } \\
\text { (USD) }\end{array}$ & $\begin{array}{c}\text { Capital Cost/Length } \\
\text { (USD/km) }\end{array}$ \\
\hline \multirow{9}{*}{$\begin{array}{l}\text { Main tunnel } \\
\text { construction }\end{array}$} & \multirow{3}{*}{ III wall rock } & Excavation & $4,014,130$ & $1,427,500$ \\
\hline & & Supporting structure & $1,130,875$ & 402,160 \\
\hline & & Tunnel lining & $6,733,658$ & $2,394,615$ \\
\hline & \multirow{3}{*}{ IV wall rock } & Excavation & $1,425,382$ & 506,893 \\
\hline & & Supporting structure & $1,134,601$ & 403,485 \\
\hline & & Tunnel lining & $3,256,025$ & $1,157,904$ \\
\hline & \multirow{3}{*}{ V wall rock } & Excavation & 909,983 & 323,607 \\
\hline & & Supporting structure & $2,107,703$ & 749,539 \\
\hline & & Tunnel lining & $2,474,313$ & 879,912 \\
\hline \multicolumn{3}{|c|}{ Open cut tunnel and Shed tunnel } & 266,106 & 94,632 \\
\hline \multicolumn{3}{|c|}{ Tunnel entrance } & 424,402 & 150,925 \\
\hline \multirow{4}{*}{\multicolumn{2}{|c|}{ Ancillary work }} & Grouted rubble & 6624 & 2356 \\
\hline & & Concrete & 17,087 & 6076 \\
\hline & & Spoil area & 277,809 & 98,794 \\
\hline & & Catenary & 69,611 & 24,755 \\
\hline \multicolumn{3}{|c|}{ Total } & 24.25 million & 8.62 million \\
\hline
\end{tabular}

After the construction of the tunnel, the railway infrastructure was constructed. The cross-section of a typical high-speed railway is shown in Figure 1. Railway components mainly include the superstructure and subgrade. The superstructure, including rail, sleeper, ballast, and sub-ballast, is the direct support of the high-speed train. Therefore, it is the most important part of the railway structure. Based on a report from the World Bank [30], railway construction costs per kilometre for a high-speed railway with a speed up to $350 \mathrm{~km} / \mathrm{h}$ are exhibited in Table 2 . It is clear that civil works for the ballast and subgrade contribute to over $70 \%$ of the railway's entire costs [31]. The construction cost of railway tunnels around the world is shown in Table 3 in which the railway construction costs are not included. It can be seen that the construction cost of this project is lower than other tunnels. However, it is to be noted that other examples are long tunnels compared to the tunnel in this study. Therefore, the construction cost is significantly lower.

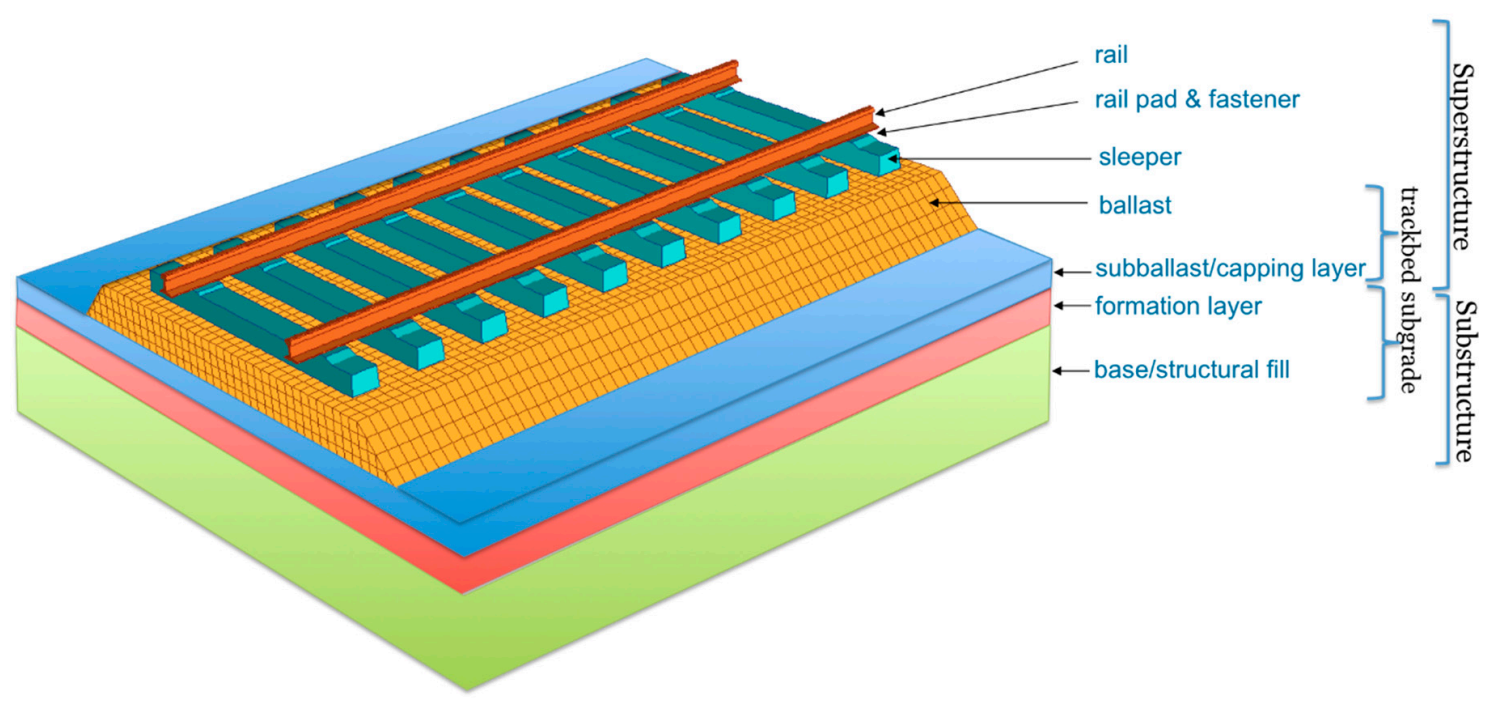

Figure 1. Railway components. 
Table 2. Railway cost.

\begin{tabular}{ccc}
\hline Components & Costs (Million USD/km) & Capital Cost (Million USD) \\
\hline Civil works (ballast and below) & 8.33 & 23.44 \\
Track (rail and sleeper) & 1.46 & 4.11 \\
Signalling and communications & 0.73 & 2.06 \\
Electrification & 0.88 & 2.47 \\
\hline
\end{tabular}

Table 3. Examples of construction cost of railway tunnels.

\begin{tabular}{|c|c|c|c|c|c|c|}
\hline Project & Tunnel & Year & $\begin{array}{l}\text { Length } \\
(\mathrm{km})\end{array}$ & Cost & $\begin{array}{l}\text { Cost (Billion } \\
\text { USD) }\end{array}$ & $\begin{array}{c}\text { Cost } / \text { Length } \\
\text { (Million USD } / \mathbf{k m} \text { ) }\end{array}$ \\
\hline \multirow{2}{*}{$\begin{array}{c}\text { Turin-Lyon } \\
\text { high-speed railway }\end{array}$} & $\begin{array}{l}\text { Mont d'Ambin Base } \\
\text { Tunnel }\end{array}$ & \multirow[b]{2}{*}{2016} & 57.5 & \multirow[b]{2}{*}{$€ 8$ billion } & \multirow[b]{2}{*}{9.4} & \multirow[b]{2}{*}{82.02} \\
\hline & $\begin{array}{l}\text { Gotthard Base } \\
\text { Tunnel }\end{array}$ & & 57.1 & & & \\
\hline Kaikyo Line & Seikan Tunnel & 1988 & 53.85 & $\begin{array}{l}¥ 1.1 \\
\text { trillion }\end{array}$ & 7 & 129.99 \\
\hline Eurostar & Channel Tunnel & 1994 & 50.45 & $£ 9$ billion & 11.8 & 233.89 \\
\hline $\begin{array}{l}\text { Suseo high-speed } \\
\text { railway }\end{array}$ & Yulhyeon Tunnel & 2016 & 50.3 & N/A & 3 & 59.64 \\
\hline $\begin{array}{l}\text { Chongqing-Lanzhou } \\
\text { railway }\end{array}$ & West Qinling Tunnel & 2016 & 28.236 & $\mathrm{~N} / \mathrm{A}$ & 11.3 & 400.20 \\
\hline $\begin{array}{c}\text { Jinghu high-speed } \\
\text { railway }\end{array}$ & Xikema & 2008 & 2.8 & $\begin{array}{l}¥ 178.56 \\
\text { million }\end{array}$ & 0.025 & 8.93 \\
\hline
\end{tabular}

\subsection{Operation and Maintenance Costs}

The operation and maintenance of the project include various costs required to maintain the normal service of the railway tunnel throughout its overall design life after the project construction. Operation costs can be classified into several main parts which are management of operation, traffic monitoring costs, and emergence costs. The maintenance costs primarily cover electrical costs, mechanical costs, and structural costs. Operation costs mainly cover labour and vehicle fees, and traffic monitoring accounts for much of the cost of monitoring systems. Considering the long service life of the monitoring system, the costs of this system are considered to be uniformly distributed over its service life. Vehicles are considered in the same way. The replacement of materials during the maintenance process is assumed to happen every two years. Due to the fact that the design life of the rail (50 years) is less than that of the tunnel (100 years), the rail needs to have major maintenance which 10.97 million USD is assumed when its operation years reach its design life. The basic annual operation and maintenance costs are estimated in Tables 4 and 5, respectively. These basic annual costs are estimated for the first year after project construction. The basic annual operation and maintenance costs are assumed to be the same for each year of operation. The economic design lives of the rail and the tunnel are 50 and 100 years respectively. 
Table 4. Operation costs.

\begin{tabular}{cccc}
\hline $\begin{array}{c}\text { Basic Annual } \\
\text { Operating Costs }\end{array}$ & Cost Components & Cost (USD/Year) & Sources \\
\hline \multirow{2}{*}{$\begin{array}{c}\text { Management of } \\
\text { operation }\end{array}$} & Manager & 11,698 & $\begin{array}{c}\text { National Bureau of } \\
\text { Statistics of China [32] }\end{array}$ \\
\cline { 2 - 4 } & 2 Office assistants & 10,236 & $\begin{array}{c}\text { National Bureau of } \\
\text { Statistics of China [32] }\end{array}$ \\
\cline { 2 - 4 } $\begin{array}{c}\text { Traffic monitoring } \\
\text { costs }\end{array}$ & 2 Cleaners & 8774 & $\begin{array}{c}\text { National Bureau of } \\
\text { Statistics of China [32] }\end{array}$ \\
\cline { 2 - 4 } & $\begin{array}{c}\text { Closed-circuit television } \\
\text { (CCTV) personnel }\end{array}$ & 8094 & Report buyer [33] \\
\hline \multirow{2}{*}{\begin{tabular}{c} 
Emergence costs \\
\cline { 2 - 4 }
\end{tabular}} & Vehicle (15 years) & 975 & National Bureau of \\
& Operators & 9505 & Caterpillar [34] \\
\hline Energy costs & Vehicle fuel & National Bureau of \\
& Total (annual): & 96,510 & Bloomberg [35] \\
\hline
\end{tabular}

Table 5. Maintenance costs.

\begin{tabular}{|c|c|c|c|}
\hline $\begin{array}{c}\text { Basic Annual } \\
\text { Maintenance Costs }\end{array}$ & Cost Components & Cost (USD/Year) & Sources \\
\hline \multirow{4}{*}{ Electrical costs } & Labour & 8042 & $\begin{array}{c}\text { National Bureau of } \\
\text { Statistics of China [32] }\end{array}$ \\
\hline & $\begin{array}{l}\text { Replacement materials } \\
\text { (every } 5 \text { years) }\end{array}$ & 29,245 & MacDonald [37] \\
\hline & Platform truck (15 years) & 731 & Caterpillar [34] \\
\hline & Truck fuel & 585 & CEIC [36] \\
\hline \multirow{4}{*}{ Mechanical costs } & Labour & 8042 & $\begin{array}{c}\text { National Bureau of } \\
\text { Statistics of China [32] }\end{array}$ \\
\hline & Replacement materials & 17,547 & MacDonald [37] \\
\hline & Vehicle (10 years) & 512 & Caterpillar [34] \\
\hline & Truck fuel & 512 & CEIC [36] \\
\hline \multirow{3}{*}{ Structure costs } & Labour & 6580 & $\begin{array}{c}\text { National Bureau of } \\
\text { Statistics of China [32] }\end{array}$ \\
\hline & $\begin{array}{l}\text { Cleaner vehicle } \\
\text { (15 years })\end{array}$ & 682 & Caterpillar [34] \\
\hline & Vehicle fuel & 731 & CEIC [36] \\
\hline \multicolumn{2}{|c|}{ Total (annual): } & 46,378 & \\
\hline
\end{tabular}

\subsection{Results of LCC}

Sections 3.1 and 3.2 have provided the capital costs and the basic annual operation and maintenance costs of the high-speed railway tunnel. The capital costs of the tunnel's construction are assumed to be the same over the two-year construction period. The costs of the railway construction shown in Table 2 are per kilometre and the total length of the tunnel is $2.812 \mathrm{~km}$. The costs of the railway construction are assumed to be invariant during the two-year construction. The operation and maintenance costs are assumed to be invariant over the whole design life of the tunnel. For a long-term cost evaluation of 
the project, two project discount rates of $1 \%$ and $4 \%$ are employed for comparison in the following LCC analysis [38]. NPV of the project can be calculated by the following equation.

$$
N P V=\sum_{t=1}^{n} \frac{R_{t}}{(1+i)^{t}}
$$

where $R_{t}$ is the net cash inflow-outflows during a single period, $t ; i$ is the discount rates which are $1 \%$ and $4 \%$ respectively; $n$ is the number of timer periods which is the design life of 100 years in this analysis.

Since both the construction and operation and maintenance stages are significant, the cost of each stage of the tunnel will be analysed using NPV values. As an accurate discount rate cannot be provided, the effect of the discount rate will also be analysed. The undiscounted and discounted cumulative costs (NPV) with regard to the years of operation are shown in Figure 2. It is clear that the cumulative costs of the construction years of the three cases are almost the same because no operation or maintenance costs exist. With the increase of the years of operation, all three cases show linear variations. However, the increased rate of the undiscounted cumulative costs (i.e., $i=0$ ) is much larger than those of the other two cases. In contrast, the cumulative costs with a discounted rate of $4 \%$ show an almost constant trend and are much smaller than those with the $1 \%$ discount rate. The final cumulative costs at 100 years for the undiscounted case are about 1.5 times those for the discounted case with a discounted rate of $1 \%$. Therefore, the discount rate can have a significant influence on the NPV of a project. In practical applications, this value can be accurately evaluated to provide a reliable cost evaluation.

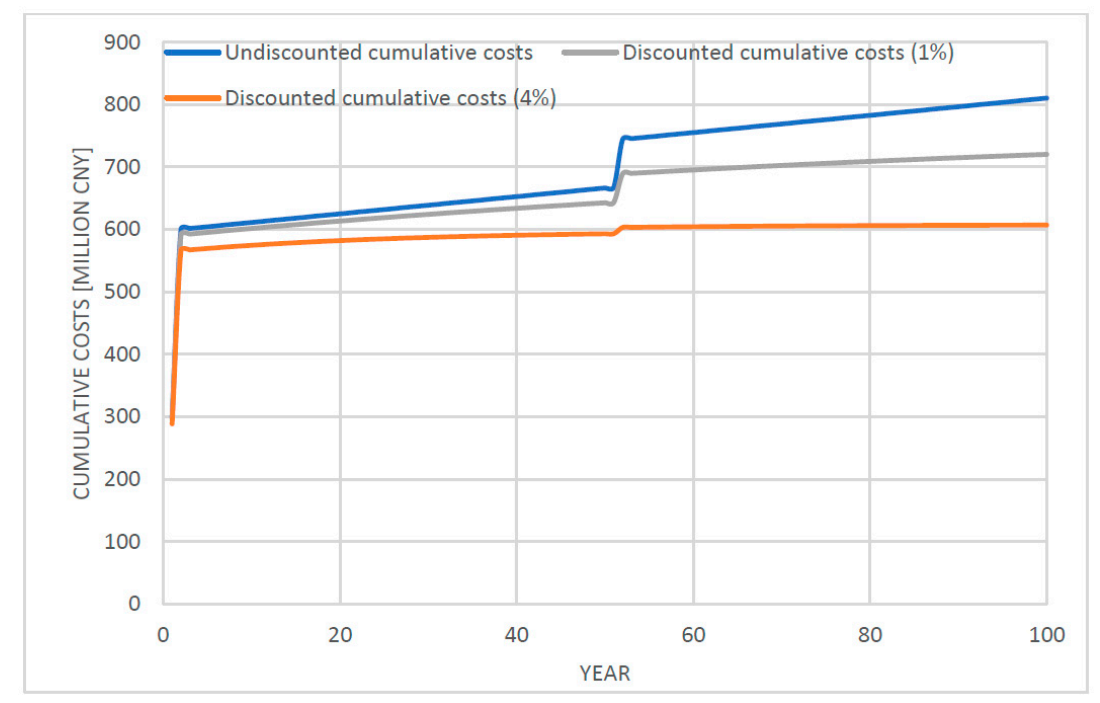

Figure 2. Undiscounted and discounted cumulative costs (net present value (NPV)).

\section{Life-Cycle Assessment (LCA)}

An LCA is conducted for the high-speed railway tunnel. Generally, life-cycle environmental impact can be classified into different aspects such as $\mathrm{CO}_{2}$ emissions, acidification, ozone depletion, photochemical oxidant formation, and eutrophication. However, this study will only consider $\mathrm{CO}_{2}$ emissions. The LCA analysis will account for several aspects such as material production in the tunnel and rail construction processes, maintenance after construction, and the transportation of construction materials. For each of these aspects, the materials used will be specified and the corresponding $\mathrm{CO}_{2}$ emissions will be estimated in detail. Moreover, life-cycle and energy consumption will also be considered. As with LCC, the different steps of tunnel construction are considered except ventilation and air conditioning which are not included in this study. 


\subsection{Material Production}

This section describes the environmental impact (i.e., $\mathrm{CO}_{2}$ emissions) and energy consumption caused by material produced during the construction process. Because the rail was constructed after the tunnel's construction, the tunnel and the rail parts will be separately considered as follows.

Table 6 shows the material characteristics of the tunnel construction process the data for which are collected from the project report [29]. Concrete is the main material for tunnel support, including both temporary and permanent support. The lining, acting as the permanent support of the tunnel, is made of pre-stressed reinforced concrete. Accelerator, a mixture made of bauxite, sodium, and unslaked lime, is mixed with the concrete to enhance the cement's mechanical properties. A waterproof rubber belt is employed for waterproofing because a great deal of water is contained in the rock mountain and waterproofing should be applied after tunnel excavation for protection purposes. Both the temporary and permanent supports utilise rebars to enhance the strength of the raw concrete. For simplicity, fuel consumption during the tunnel excavation process is also accounted for in this material production portion. The working period is assumed to be 600 days with eight working hours per day. The total fuel consumption is taken as $8 \mathrm{~L} / \mathrm{hr}$. Table 7 shows the $\mathrm{CO}_{2}$ emissions and energy consumption of material production for the tunnel's construction. It is clear that the main contribution of $\mathrm{CO}_{2}$ emissions is concrete production while the waterproof rubber belt consumes the most energy. These features are mainly related to the nature of the material production processes.

Table 6. Material characteristics for tunnel construction.

\begin{tabular}{cccc}
\hline Material & Quantity & $\begin{array}{c}\mathrm{CO}_{2} \text { Emissions } \\
\text { Coefficients }\left(\mathrm{gCO}_{2} / \mathbf{k g}\right)\end{array}$ & $\begin{array}{c}\text { Energy Consumption } \\
(\mathbf{M J} / \mathbf{k g})\end{array}$ \\
\hline Concrete & $14.9 \mathrm{ton} / \mathrm{m}$ & 885.1 & 3.71 \\
Accelerator & $113 \mathrm{~kg} / \mathrm{m}$ & 1306.8 & 31.65 \\
Waterproof rubber belt & $9.0 \mathrm{~m} / \mathrm{m}$ & 580.9 & 79.29 \\
Rebar & $2033.4 \mathrm{~kg} / \mathrm{m}$ & 1060 & 14.38 \\
Fuel & $4 \mathrm{~L} / \mathrm{hr}$ & 72.09 & 56.26 \\
\hline
\end{tabular}

Table 7. $\mathrm{CO}_{2}$ emissions and energy consumption of material production for tunnel construction.

\begin{tabular}{cccc}
\hline Material & Total Mass (Ton) & $\mathbf{C O}_{\mathbf{2}}$ Emissions (Ton) & Energy Consumption $\left(\times \mathbf{1 0}^{\mathbf{6}} \mathbf{M J}\right)$ \\
\hline Concrete & $41,898.8$ & 37,085 & 155 \\
Accelerator & 317.8 & 415.3 & 10.1 \\
Waterproof rubber belt & 7703.8 & 4475.1 & 610.8 \\
Rebar & 5717.9 & 6061.1 & 82.2 \\
Fuel & 16.32 & 1.2 & 0.92 \\
\hline
\end{tabular}

Table 7 summarises the material $\mathrm{CO}_{2}$ emission and energy consumption for rail construction. As shown in Figure 1, ballast, sleepers, rails, and elastomeric pads are the main components of the rail system. Ballast is constructed of gravel with an average density of $2000 \mathrm{~kg} / \mathrm{m}^{3}$. The average thickness and width of the cross-section of the rail are 0.3 and $3.95 \mathrm{~m}$, respectively. These dimensions can help evaluate the total volume and mass of ballast used for this rail. Sleepers are made from pre-stressed reinforced concrete and are distributed at a centre-to-centre distance of $0.6 \mathrm{~m}$. The weight of a single sleeper is around $280 \mathrm{~kg}$. Rails are made from steel with a weight of $60.4 \mathrm{~kg} / \mathrm{m}$. The steel fastening system is used to connect rails to sleepers and the weight of each fastener is about $2.4 \mathrm{~kg}$. Elastomeric pads, which are placed between the rail and sleeper, act as dampers that can absorb energy caused by trains and reduce vibrations during operation. They are made of ethylene-vinyl acetate and a single sleeper weighs $1 \mathrm{~kg}$. Similar to the tunnel materials, for simplicity, fuel for ballast extraction, railway profiling, and track stabilisation is also accounted for in this portion. The working period is assumed to be 280 days with 8 working hours per day. The total fuel consumption is also taken as $8 \mathrm{~L} / \mathrm{hr}$. 
Table 8 presents the $\mathrm{CO}_{2}$ emissions and energy consumption coefficients of material production for rail construction. Table 9 presents the $\mathrm{CO}_{2}$ emission and the energy consumption of each material from the rail construction. It is clear that sleepers and rails contribute the most to $\mathrm{CO}_{2}$ emissions because their materials are concrete and steel, respectively. This finding is confirmed by Bizjak et al. [39], Steele [40] and Lee et al. [41]. However, the energy consumption of the rail system seems to be negligible compared with that of the tunnel [42].

Table 8. Material characteristics for rail construction.

\begin{tabular}{cccc}
\hline Material & Dimensions & $\begin{array}{c}\mathbf{C O}_{2} \text { Emissions Coefficients } \\
\left(\mathbf{g C O}_{\mathbf{2}} \mathbf{k g}\right)\end{array}$ & $\begin{array}{c}\text { Energy Consumption } \\
\mathbf{( M J} / \mathbf{k g})\end{array}$ \\
\hline Ballast & $\begin{array}{c}\text { Thickness of } 0.3 \mathrm{~m} ; \\
\text { Width of } 3.95 \mathrm{~m}\end{array}$ & 0.037 & 0.04 \\
\hline Sleepers & $280 \mathrm{~kg}$ per sleeper & 885.1 & 3.71 \\
\hline Rails & $60.4 \mathrm{~kg} / \mathrm{m}$ & 1690 & 16.4 \\
\hline Fastening system & $2.4 \mathrm{~kg}$ per sleeper & 1690 & 16.4 \\
\hline Elastomeric pads & $1 \mathrm{~kg}$ per sleeper & 580.9 & 79.29 \\
\hline Fuel & $8 \mathrm{~L} / \mathrm{hr}$ & 72.09 & 56.26 \\
\hline
\end{tabular}

Table 9. $\mathrm{CO}_{2}$ emissions and energy consumption of material production for rail construction.

\begin{tabular}{cccc}
\hline Material & Total Mass (Ton) & $\mathbf{C O}_{\mathbf{2}}$ Emissions (Ton) & $\begin{array}{c}\text { Energy Consumption } \\
\left(\times \mathbf{1 0}^{\mathbf{6}} \mathbf{~ M J )}\right.\end{array}$ \\
\hline Ballast & 6664.4 & 0.25 & 0.27 \\
Sleepers & 1312.3 & 1161.5 & 4.9 \\
Railway & 169.8 & 287.0 & 2.8 \\
Fastening system & 11.2 & 18.9 & 0.18 \\
Elastomeric pads & 4.7 & 2.7 & 0.37 \\
Fuel & 15.2 & 1.1 & 0.86 \\
\hline
\end{tabular}

\subsection{Maintenance}

For the operation and maintenance process, the primary environmental impact is induced by vehicle fuel consumed by emergency vehicles and maintenance trucks and the electricity supply for normal operations. Table 10 lists the average fuel and electricity usage per year. The fuel for the emergence vehicles is estimated to be $2381 \mathrm{~L} / \mathrm{yr}$. The electricity consumed by the monitoring system is assumed to be $910,345 \mathrm{kWh} / \mathrm{yr}$. Moreover, the fuel for maintenance trucks (i.e., the platform truck and vehicles for mechanical and structural maintenance) is around $1984 \mathrm{~L} / \mathrm{yr} . \mathrm{CO}_{2}$ emissions and energy consumption are also calculated based on their corresponding $\mathrm{CO}_{2}$ emission and energy consumption coefficients, which are also exhibited in Table 10.

Table 10. Basic annual maintenance.

\begin{tabular}{cccc}
\hline & Activity & $\mathbf{C O}_{\mathbf{2}}$ Emissions (Ton/Yr) & Energy Consumption $\left(\times \mathbf{1 0}^{\mathbf{6}} \mathbf{M J}\right)$ \\
\hline Electricity & $\begin{array}{c}\text { Monitoring system, } \\
910,345 \mathrm{~kW} \cdot \mathrm{h} / \mathrm{yr}\end{array}$ & 14.6 & 10.6 \\
\hline Truck fuel & $\begin{array}{c}\text { Platform truck and } \\
\text { vehicle for mechanical } \\
\text { and structural } \\
\text { maintenance; } 1984 \mathrm{~L} / \mathrm{yr}\end{array}$ & 0.12 & 0.09 \\
\hline
\end{tabular}




\subsection{Transportation}

Transportation mainly accounts for the transport of construction materials. Depending on the total weight and distance, truck and rail transport are considered. Since concrete mainly refers to the lining pre-cast in the factory, concrete materials are directly transported a long distance $(300 \mathrm{~km})$ by trucks from the factory for long distances. The accelerator and waterproof rubber belt are also from the factory using trucks with distances of 400 and $300 \mathrm{~km}$, respectively. However, due to the weight and shape of rail materials, most rail materials (i.e., ballast, sleepers, rails, and fastening systems) are transported using trains. The elastomeric pads are assumed to be transported using three trucks due to their small volume. The transportation distances, fuel consumption, and the corresponding $\mathrm{CO}_{2}$ emissions and energy consumption are detailed in Table 11.

Table 11. Transportation characteristics.

\begin{tabular}{cccc}
\hline Material & $\begin{array}{c}\text { Transport Type, Distance, } \\
\text { and Fuel }\end{array}$ & $\begin{array}{c}\mathbf{C O}_{\mathbf{2}} \text { Emissions } \\
(\text { Ton) }\end{array}$ & $\begin{array}{c}\text { Energy Consumption } \\
\left(\times \mathbf{1 0}^{\mathbf{6}} \mathbf{M J}\right)\end{array}$ \\
\hline Concrete & 5 Trucks; $300 \mathrm{~km} ; 0.08 \mathrm{~L} / \mathrm{km}$ & 0.0074 & 0.0057 \\
Accelerator & Truck; $400 \mathrm{~km} ; 0.08 \mathrm{~L} / \mathrm{km}$ & 0.0020 & 0.0015 \\
Waterproof rubber belt & Truck; $300 \mathrm{~km} ; 0.08 \mathrm{~L} / \mathrm{km}$ & 0.0015 & 0.0011 \\
Rebar & 2 Trucks; $300 \mathrm{~km} ; 0.08 \mathrm{~L} / \mathrm{km}$ & 0.0030 & 0.0023 \\
Ballast & Train; $50 \mathrm{~km} ; 7.9 \mathrm{~L} / \mathrm{km}$ & 0.024 & 0.019 \\
Sleepers & Train; $80 \mathrm{~km} ; 7.9 \mathrm{~L} / \mathrm{km}$ & 0.039 & 0.03 \\
Rails & Train; $400 \mathrm{~km} ; 7.9 \mathrm{~L} / \mathrm{km}$ & 0.194 & 0.15 \\
Fastening system & Train; $400 \mathrm{~km} ; 7.9 \mathrm{~L} / \mathrm{km}$ & 0.194 & 0.15 \\
Elastomeric pads & 3 Trucks; $300 \mathrm{~km} ; 0.08 \mathrm{~L} / \mathrm{km}$ & 0.004 & 0.0034 \\
\hline
\end{tabular}

\subsection{Results of LCA}

Based on the above analysis, the total $\mathrm{CO}_{2}$ emissions and energy consumption during different processes is summarised in Table 12. Three overall processes are considered which are tunnel construction, rail construction, and maintenance. For the tunnel and rail construction processes, the total $\mathrm{CO}_{2}$ emissions and energy consumption account for the environmental impact of both material production and transportation. In terms of the maintenance process, the annual $\mathrm{CO}_{2}$ emissions and energy consumption estimated in Table 10 are assumed to be the same for each operating year. As mentioned before, the design life of this tunnel is 100 years. The total $\mathrm{CO}_{2}$ emissions and energy consumption are also graphically illustrated in Figure 3.

Table 12. Life-cycle $\mathrm{CO}_{2}$ emissions (ton) and energy consumption $\left(\times 10^{6} \mathrm{MJ}\right)$.

\begin{tabular}{cccc}
\hline \multirow{2}{*}{ Process } & $\begin{array}{c}\mathbf{C O}_{\mathbf{2}} \text { Emissions } \\
(\text { Ton })\end{array}$ & $\begin{array}{c}\text { Energy Consumption } \\
\left(\times \mathbf{1 0}^{\mathbf{6}} \mathbf{M J}\right)\end{array}$ \\
\hline \multirow{2}{*}{ Construction } & Tunnel (material production and transport) & 48,038 & 859 \\
\cline { 2 - 4 } & Rail (material production and transport) & 1472 & 10 \\
\hline Maintenance & 1472 & 1069 \\
\hline
\end{tabular}

As shown in Figure 3a, the tunnel construction process contributes about $94.2 \%$ of the overall life-cycle $\mathrm{CO}_{2}$ emissions. This is due to a large amount of concrete consumed, which also has a much higher $\mathrm{CO}_{2}$ emission coefficient than the other materials. The $\mathrm{CO}_{2}$ emissions induced by the rail construction process are comparable with those produced by the maintenance process. The construction process (i.e., both tunnel and rail construction) contributes approximately $97.1 \%$ of the life cycle's $\mathrm{CO}_{2}$ emissions and the $\mathrm{CO}_{2}$ emissions caused by the maintenance process appear to be negligible compared with the construction process. However, Figure $3 \mathrm{~b}$ shows that about $55.2 \%$ of life-cycle energy consumption can be attributed to the maintenance process. The energy consumption of the 
tunnel construction process is approximately $44.3 \%$ and the portion from the rail construction is much smaller (less than 1\%) and can be ignored.

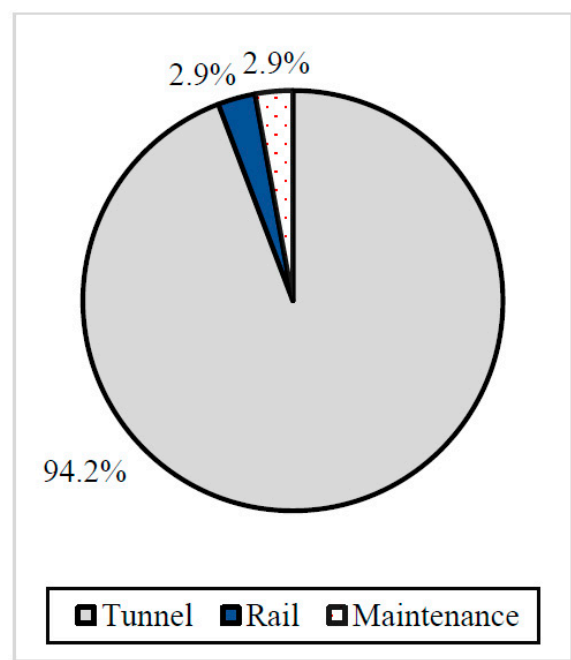

(a)

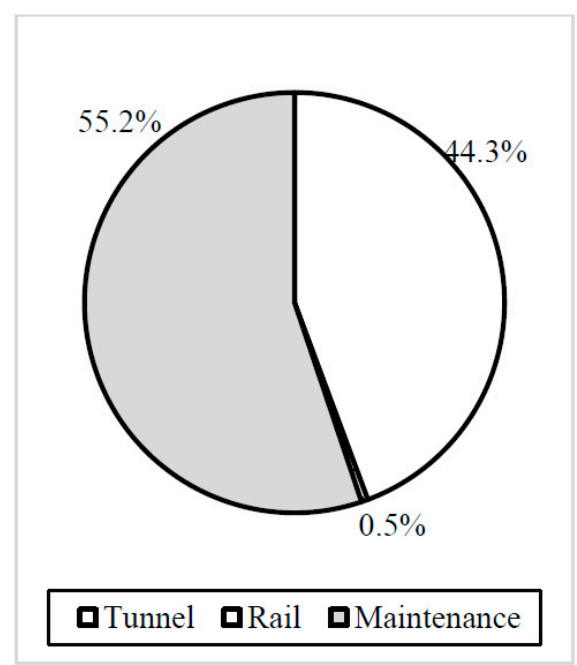

(b)

Figure 3. $\mathrm{CO}_{2}$ emissions and energy consumption: (a) $\mathrm{CO}_{2}$ emissions (ton) and (b) energy consumption $\left(\times 10^{6} \mathrm{MJ}\right)$.

\section{Conclusions}

This paper has performed an analysis of the life-cycle costs and life-cycle assessment of the Xikema No. 1 high-speed railway tunnel in China. In terms of the LCC analysis, the initial capital costs (i.e., tunnel and rail construction), and operation and maintenance costs have been separately considered. NPV values, with the different discounted rates of the project, have also been estimated. The results show that the discounted rate has a great influence on NPV values. In the LCA analysis, the $\mathrm{CO}_{2}$ emissions and energy consumption during the life of the overall design has been accounted for. The LCA analysis shows that the materials used in the construction process (i.e., tunnel and rail construction) contribute over $97 \%$ of the life cycle's $\mathrm{CO}_{2}$ emissions, and the $\mathrm{CO}_{2}$ emissions caused by the maintenance process are relatively small compared to that of the construction process. In addition, the maintenance process consumes about $55.2 \%$ of the life-cycle energy. The energy consumption of the tunnel construction process is around $44.3 \%$, and the portion from the rail construction can be ignored.

This analysis can provide important practical implications. The LCC analysis shows that the construction stage contributes the most to the overall cost; therefore, more cost-effective construction measures can be taken to reduce the life-cycle costs of a railway tunnel. Due to the fact that the production of concrete and steel always emits a great deal of $\mathrm{CO}_{2}$, more environmentally friendly materials could be applied to minimise their environmental impact.

Author Contributions: Conceptualization, S.K. and S.Y.; Data curation, S.Y.; Formal analysis, S.Y.; Investigation, S.Y.; Methodology, S.Y.; Project administration, S.K.; Resources, S.K.; Supervision, S.K.; Validation, S.Y.; Visualization, S.Y.; Writing - original draft, S.Y.; Writing—review and editing, J.S. All authors have read and agreed to the published version of the manuscript.

Funding: This research was funded by the European Commission for the financial sponsorship of the H2020-MSCA-RISE Project No. 691135 "RISEN: Rail Infrastructure Systems Engineering Network”, which enables a global research network that tackles the grand challenge in railway infrastructure resilience and advanced sensing. The APC is sponsored by the MDPI's Invited Paper Initiative.

Acknowledgments: The authors are sincerely grateful to European Commission for the financial sponsorship of the H2020-MSCA-RISE Project No. 691135 “RISEN: Rail Infrastructure Systems Engineering Network," which enables a global research network that tackles the grand challenge of railway infrastructure resilience and advanced sensing in extreme environments (www.risen2rail.eu) [43].

Conflicts of Interest: The authors declare no conflict of interest. 


\section{References}

1. Rungskunroch, P.; Yang, Y.; Kaewunruen, S. Does High-Speed Rail Influence Urban Dynamics and Land Pricing? Sustainability 2020, 12, 3012. [CrossRef]

2. Sresakoolchai, J.; Kaewunruen, S. The effects on project of public private partnership and traditional approach in investment of The High-Speed Rail Linking 3 Airports, Thailand. Transp. Res. Interdiscip. Perspect. 2020, 5, 100116. [CrossRef]

3. Kaewunruen, S.; Osman, M.H.B.; Rungskunroch, P. The Total Track Inspection. Front. Built Environ. 2019, 4, 84. [CrossRef]

4. Osman, M.H.; Kaewunruen, S. Value of rescheduling of rail inspection. Proc. Inst. Mech. Eng. Pt. F J. Rail Rapid Transit. 2020, 234, 321-330. [CrossRef]

5. Givoni, M. Development and impact of the modern high-speed train: A review. Transp. Rev. 2006, 26, 593-611.

6. Levinson, D.; Mathieu, J.M.; Gillen, D.; Kanafani, A. The full cost of high-speed rail: An engineering approach. Ann. Reg. Sci. 1997, 31, 189-215.

7. Kagiyama, R. Japan's High-Speed Rail System between Osaka and Tokyo and Commitment to Maglev Technology: A Comparative Analysis with California's High Speed Rail Proposal between Sanjose/San Francisco Bay Area and Los Angeles Metropolitan Area; MTI Report MSTM 00-4; International Institute for Surface Transportation Policy Studies: San Jose, CA, USA, 2000.

8. De Rus Mendoza, G. Economic Analysis of High Speed Rail in Europe; Fundacion BBVA: Bilbao, Spain, 2012.

9. Kirk, S.J.; Dell'Isola, A.J. Life Cycle Costing for Design Professionals; McGraw-Hill: New York, NY, USA, 1995.

10. Andrade, A.R. Renewal Decisions from a Life-Cycle Cost (LCC) Perspective in Railway Infrastructure: An Integrative Approach Using Separate LCC Models for Rail and Ballast Components. Master's Thesis, Universidade Técnica de Lisboa, Lisbon, Portugal, 2008.

11. Zhao, J.; Chan, A.H.C.; Stirling, A.B.; Madelin, K.B. Optimizing policies of railway ballast tamping and renewal. Transp. Res. Rec. 2006, 1943, 50-56.

12. Wilson, A. Asset Maintenance Management: A Guide to Developing Strategy \& Improving Performance; Industrial Press Inc.: New York, NY, USA, 2002.

13. Patra, A.P. RAMS and LCC in Rail Track Maintenance; Luleå Tekniska Universitet: Luleå, Sweden, 2007.

14. Flanagan, R.; Norman, G.; Furbur, J.D. Life Cycle Costing for Construction; Surveyors Publications: Melbourne, Australia, 1989.

15. Kaewunruen, S.; Sussman, J.M.; Einstein, H.H. Strategic framework to achieve carbon-efficient construction and maintenance of railway infrastructure systems. Front. Environ. Sci. 2015, 3, 6. [CrossRef]

16. Kaewunruen, S.; Sresakoolchai, J.; Peng, J. Life Cycle Cost, Energy and Carbon Assessments of Beijing-Shanghai High-Speed Railway. Sustainability 2020, 12, 206. [CrossRef]

17. Chessa, A.G.; Dekker, R.; Van Vliet, B.; Steyerberg, E.W.; Habbema, J.D.F. Correlations in uncertainty analysis for medical decision making: An application to heart-valve replacement. Med. Decis. Mak. 1999, 19, $276-286$. [CrossRef] [PubMed]

18. Grossrieder, C. Life-Cycle Assessment of Future High-Speed Rail in Norway; Institutt for Energi-og Prosessteknikk: Trondheim, Norway, 2011.

19. Qian, S.; Hamdany, A. Life Cycle Assessment of Green Buildings: A Literature Review. In Proceedings of the 4th International Symposium on Life-Cycle Civil Engineering (IALCCE2014), Tokyo, Japan, 16-19 November 2014.

20. Yue, Y. Life Cyle Assessment of China's High Speed Rail System; Center for Sustainable Systems Report No. CSS13-26; University of Michigan: Ann Arbor, MI, USA, 2013.

21. Du, G.; Karoumi, R. Life cycle assessment of a railway bridge: Comparison of two superstructure designs. Struct. Infrastruct. Eng. 2013, 9, 1149-1160. [CrossRef]

22. Vandanjon, P.O.; Coiret, A.; Muresan, B.; Fargier, A.; Dauvergne, M.; Bosquet, R.; Jullien, A.; Francois, D.; Labarthe, F. Practical Guidelines for Life Cycle Assessment Applied to Railways Project. In Proceedings of the International Symposium Life Cycle Assessment and Construction, Nantes, France, 10-12 July 2012.

23. Steele, K.; Cole, G. Environmental sustainability for bridge management. In Bridge Management 5: Inspection, Maintenance, Assessment and Repair: Proceedings of the 5th International Conference on Bridge Management, Organized by the University of Surrey, 11-13 April 2005; Thomas Telford Publishing: London, UK, 2005. 
24. Gervasio, H.; da Silva, L.S.; Perdigao, V.; Barros, P.; Orcesi, A.; Nielsen, K. Life cycle analysis of highway composite bridges. In Proceedings of the IABMAS 2012 International Conference on Bridge Maintenance, Safety and Management, Stresa, Italy, 8-12 July 2012.

25. Linneberg, P.; Solgaard, A.; Eriksen, K.; Jensen, J. Challenges within Life Cycle Cost (LCC) studies and Life Cycle Assessment (LCA). In Proceedings of the Bridge Maintenance, Safety, Management and Life Extension, Shanghai, China, 7-11 July 2014.

26. Kaewunruen, S.; Lian, Q. Digital twin aided sustainability-based lifecycle management for railway turnout systems. J. Clean. Prod. 2019, 228, 1537-1551. [CrossRef]

27. Kaewunruen, S.; Xu, N. Digital Twin for Sustainability Evaluation of Railway Station Buildings. Front. Built Environ. 2018, 4, 77. [CrossRef]

28. Kaewunruen, S.; Sresakoolchai, J.; Zhou, Z. Sustainability-Based Lifecycle Management for Bridge Infrastructure Using 6D BIM. Sustainability 2020, 12, 2436. [CrossRef]

29. Sinohycro Corporation. Construction Organization Design of Xikema No. 1 Railway Tunnel. 2007. Available online: http://www.doc88.com/p-1846819166462.html (accessed on 20 July 2019).

30. Ollivier, G.; Sondhi, J.; Zhou, N. High-Speed Railways in China; World Bank: Beijing, China, 2014.

31. Profillidis, V. Railway Management and Engineering; Routledge: Abingdon, UK, 2016.

32. National Bureau of Statistics of China. China Statistical Yearbook; China Statistics Press: Beijing, China, 2010.

33. Markets and Markets. Tunnel Monitoring System Market by Offering, Tunnel Type, Networking Technologies And Region-Global Forecast to 2023; Markets and Markets: Pune, India, 2018.

34. Caterpillar, UTILITY VEHICLES. 2019. Available online: https://www.constructionequipment.com/caterpillarcuv82-cuv102d-utility-vehicles (accessed on 20 July 2019).

35. Bloomberg. Gasoline Prices Around the World: The Real Cost of Filling Up. 2019. Available online: https://www.bloomberg.com/graphics/gas-prices/\#20193:United-States:USD:g (accessed on 20 July 2019).

36. CEIC. China Electricity Price. 2019. Available online: https://www.ceicdata.com/en/china/electricity-price (accessed on 20 July 2019).

37. Hatch Mott MacDonald. Fixed Link between Labrador and Newfoundland, Pre-Feasibility Study, Final Report; Hatch Mott MacDonald: Iselin, NJ, USA, 2010.

38. Le Maout, E.; Kato, H. Life cycle cost-estimation model for building, operating, and maintaining high-speed rail systems. Asian Transp. Stud. 2016, 4, 245-260.

39. Bizjak, K.F.; Knez, F.; Lenart, S.; Slanc, K. Life-cycle assessment and repair of the railway transition zones of an existing bridge using geocomposite materials. Struct. Infrastruct. Eng. 2016, 13, 331-344. [CrossRef]

40. Steele, K. Life cycle assessment and environmental profiling of building materials. In Materials for Energy Efficiency and Thermal Comfort in Buildings; Elsevier: Amsterdam, The Netherlands, 2010; pp. 175-192.

41. Lee, J.-Y.; Lee, C.-K.; Chun, Y.-Y. Greenhouse gas emissions from high-speed rail infrastructure construction in Korea. Transp. Res. Part D Transp. Environ. 2020, 87, 102514.

42. de Melo, A.L.O.; Kaewunruen, S.; Papaelias, M.; Bernucci, L.L.B.; Motta, R. Methods to Monitor and Evaluate the Deterioration of Track and Its Components in a Railway In-Service: A Systemic Review. Front. Built Environ. 2020, 6, 118. [CrossRef]

43. Kaewunruen, S.; Sussman, J.M.; Matsumoto, A. Grand Challenges in Transportation and Transit Systems. Front. Built Environ. 2016, 2, 4. [CrossRef]

(C) 2020 by the authors. Licensee MDPI, Basel, Switzerland. This article is an open access article distributed under the terms and conditions of the Creative Commons Attribution (CC BY) license (http://creativecommons.org/licenses/by/4.0/). 